\title{
Chronic low-grade postoperative endophthalmitis in a child with Marfan syndrome
}

\author{
Darakhshanda Khurram \\ Butt ${ }^{\prime}$ \\ Robert A Scott ${ }^{1,2}$ \\ Muralidharan R Upendran' \\ 'Moorfields Eye Hospital, Dubai, UAE; \\ ${ }^{2}$ SpaMedica, Manchester, UK
}

This article was published in the following Dove Press journal:

International Medical Case Reports Journal

15 November 2017

Number of times this article has been viewed

\begin{abstract}
This case report describes a 9-year-old male who presented to the emergency department with 2 days' history of left painful red eye. On initial examination, his outside medical records indicated that he had bilateral subluxated lenses and had undergone left eye lensectomy with glued intrascleral fixation of an intraocular lens 8 weeks earlier. Vision in left eye was poor from first postoperative day but with no undue pain or redness, and poor vision was attributed to possible vitreous bleed. Subsequent postoperative course was uneventful. He was discharged from ophthalmic care on topical steroids and antibiotic drops, one week postsurgery. The eye was healing well until he developed pain, for which ophthalmic care was sought. He underwent anterior chamber tap with intravitreal injections. Aqueous samples were positive for Staphylococcus aureus DNA by polymerase chain reaction. Post vitrectomy and implant removal, his recovery was good and vision improved to $0.50 \mathrm{LogMar}$ with aphakic correction.
\end{abstract}

Keywords: glued intrascleral fixation IOL, subluxated lens, post-op endophthalmitis

\section{Introduction}

Endophthalmitis is rare but serious complication of intraocular surgery and often causes severe visual impairment or even the loss of an eye. The importance of close postoperative follow-up in pediatric intraocular surgery cannot be overemphasized. This is essential for early recognition of signs and symptoms of infection and timely management.

\section{Case report}

This 9 year old male presented with a 2 day history of a red, painful left eye with poor vision. He had previously undergone a left lensectomy with intrascleral intraocular lens (IOL) fixation using fibrin glue, at another hospital, overseas. The indication for surgery was for a subluxed crystalline lens associated with Marfan syndrome.

The left vision remained poor from first postoperative day, attributed to a presumed vitreous hemorrhage, as there was no undue pain or redness. He was discharged from the hospital to his local ophthalmologist after 1 week with topical steroid and antibiotic drops. He was reviewed at 4 weeks postoperatively at which time his vision was perception of light/vague hand movements; he first presented to our unit when the eye became painful 8 weeks postoperatively.

On examination, the right LogMar visual acuity was 0.10 with a myopic correction and light perception on the left. There was a left relative afferent pupillary defect, and the right pupil was reactive while the left was fixed, unresponsive, and mid-dilated.

Correspondence: Darakhshanda Khurram Butt

Moorfields Eye Hospital, 64 Al Razi Building, 3rd Floor DHCC, Dubai 505054, UAE

Email drdk.74@gmail.com 
He had marked left photosensitivity and difficulty opening the left eye. The intraocular pressures were $14 \mathrm{mmHg}$ on the right and $41 \mathrm{mmHg}$ on the left.

Slit-lamp biomicroscopy demonstrated right superotemporal lens subluxation; the left eye was injected with associated conjunctival chemosis. The corneal section had healed and the sutures had dissolved, but there was marked corneal edema and haze. The anterior chamber (AC) had red blood cells with mild flare, but no hypopyon. The IOL was tilted and off-center with pupillary capture. Fundal examination was impossible due to the corneal haze. B-scan ultrasonography showed diffuse vitreous haze and choroidal thickening with a flat retina. The full blood count was normal.

The patient was given intravenous mannitol that lowered his intraocular p pressure to $20 \mathrm{mmHg}$. He had a surgical AC washout with ocular examination under general anesthesia. There was significant fibrin in the AC, purulent material filling vitreous cavity, and a necrotic retina fundal fibrotic tissue. An AC tap with intravitreal injection of vancomycin (1 $\mathrm{mg} / 0.1 \mathrm{~mL})$ and ceftazidime $(2.5 \mathrm{mg} / 0.1 \mathrm{~mL})$ was performed.

The initial Gram stain and culture was negative, but polymerase chain reaction revealed Staphylococcus aureus DNA. Postoperatively, the vision remained at light perception and the intraocular pressure remained high. A vitrectomy with implant removal, endolaser, and Silicon oil injection was then performed. The vision improved after this procedure, and the silicone oil was removed 4 weeks afterwards. At 6 months, his best-corrected left LogMar vision was 0.50 , with an aphakic contact lens correction.

\section{Ethics}

Written informed consent was provided by the patient's parents to have the case details published.

\section{Discussion}

Increasing number of patients from the United Arab Emirates are seeking medical care outside their home country for a number of reasons. These include access to high-quality affordable health care with the private health care facilities and reduced waiting times. There are risks associated with such medical tourism such as concerns about the quality of medical and surgical care available, though there is no evidence supporting this. ${ }^{1-3}$
One of the biggest risks of medical tourism is infection. ${ }^{4}$ Postcataract endophthalmitis is widely reported, but was difficult to diagnose in this case, due to incomplete medical records. ${ }^{5}$ In addition, it was difficult to evaluate the potential impact of factors such as variations in surgical technique, intraoperative antibiotics, surgical time, or complications during cataract surgery to the diagnosis of endophthalmitis. All of this was further compounded by the lack of postoperative follow-up and appropriate transfer of care.

Culture and microscopy with a Gram stain of aqueous and vitreous aspirates are traditionally used to diagnose postoperative endophthalmitis. ${ }^{6}$ These are negative in around $30 \%$ of cases due to insufficient culture sample, or inadequate culture techniques. ${ }^{7}$ Polymerase chain reaction identification of bacterial DNA has recently emerged as an effective diagnostic tool that has improved bacterial and fungal detection and identification, particularly in chronic, low-grade bacterial endophthalmitis. ${ }^{8-10}$ As with our case, this allows for effective antibiotic targeting and surgical management.

\section{Disclosure}

The authors report no conflicts of interest in this work.

\section{References}

1. Crooks VA, Kingsbury P, Snyder J, et al. What is known about the patient's experience of medical tourism? A scoping review. BMC Health Serv Res. 2010;10:266.

2. Crone RK. Flat medicine? Exploring trends in the globalization of health care. Acad Med. 2008;83:117.

3. Wright IG, Walker IA, Yacoub MH. Specialist surgery in the developing world: luxury or necessity? Anaesthesia. 2007;62(Suppl 1):84-89.

4. Penney K, Snyder J, Crooks VA, et al. Risk communication and informed consent in the medical tourism industry: a thematic content analysis of Canadian broker websites. BMC Med Ethics. 2011;12:17.

5. Gupta A, Gupta V, Gupta A, et al. Spectrum and clinical profile of post cataract surgery endophthalmitis in north India. Indian J Ophthalmol. 2003;51:139-145.

6. Kamalarajah S, Ling R, Silvestri G, et al. Presumed infectious endophthalmitis following cataract surgery in the UK: a case-control study of risk factors. Eye. 2007;21(5):580-586.

7. Goldschmidt P, Degorge S, Benallaoua D, et al. New test for the diagnosis of bacterial endophthalmitis. Br J Ophthalmol. 2009;93(8):1089-1095.

8. Hykin PG, Tobal K, McIntyre G, et al. The diagnosis of delayed postoperative endophthalmitis by polymerase chain reaction of bacterial DNA in vitreous samples. J Med Microbiol.1994;40:408-415.

9. Sugita S, Kamoi K, Ogawa M, et al. Detection of Candida and Aspergillus species DNA using broad-range real-time PCR for fungal endophthalmitis. Graefes Arch Clin Exp Ophthalmol. 2012;250(3):391-398.

10. Bispo PJ, De Melo GB, Hofling-Lima AL, et al. Detection and Gram discrimination of bacterial pathogens from aqueous and vitreous humor using real-time PCR assays. Invest Ophthalmol Vis Sci. 2011;52(2):873-881. 
International Medical Case Reports Journal

The International Medical Case Reports Journal is an international, peer-reviewed open-access journal publishing original case reports from all medical specialties. Previously unpublished medical posters are also accepted relating to any area of clinical or preclinical science. Submissions should not normally exceed 2,000 words or
4 published pages including figures, diagrams and references. The manuscript management system is completely online and includes a very quick and fair peer-review system, which is all easy to use. Visit $\mathrm{http}: / /$ www.dovepress.com/testimonials.php to read real quotes from published authors.

Submit your manuscript here: https://www.dovepress.com/international-medical-case-reports-journal-journal 